\title{
The preventive effect of cooked and germinated legumes on some disturbances accompanied with aging
}

\author{
Elbostany. A.Nahla ${ }^{1}$ and Reda M.S.Korany ${ }^{2}$ \\ ${ }^{1}$ Special Food and Nutrition Dep. Food Technology Research Institute, Agric. Res. \\ Center.Giza \\ ${ }^{2}$ Histopathology Dep. Faculty of Veterinary, Cairo University.
}

\begin{abstract}
Legume consumption may play an important role on the health life during aging through its well-recognized antioxidant, antiproliferative, and antigenotoxic effects. The present study aimed to clarify the effect of some legumes feeding on oxidative stress in menopause rats. The experiment was carried out on 66 female rats (16-17 months old) divided into 11 groups. The first group was fed basal diet and kept as control group. The remaining groups were fed basal diet containing $20 \%$ of different processed legumes either cooked or germinated (faba bean, chickpea, lentil, white bean and fenugreek). The experiment continued for 8 weeks. Growth of rats, biochemical analyses and histopathological examination were evaluated. Results showed that the body weight changed from the highest percentage of decrease ($7.7 \%)$ in the group fed on diet including germinated white bean and the highest percentage of increase $(+7.1 \%)$ in the group fed cooked lentil supplemented diet. The study also demonstrated improvement in lipid profile, particularly in VLDL-C and triglycerides levels. The highest percentage decreases of atherogenic index relative to control group were 46.5, 44 and $40 \%$ in groups supplemented with germinated lentil, cooked faba bean and germinated faba bean, respectively. Germination process is more effective than cooking treatment by enhancing the antioxidant enzymes such as SOD and GPx, also by reducing liver enzymes like, alkaline phosphatase and aspartate transferase, particularly germinated lentil group and decreasing lipid peroxidation reflected on histopathological lesions in hepatocytes. Moreover, serum protein was higher in germinated legumes diets than cooked ones. In conclusion, the obtained results suggest that diets containing legumes, particularly the germinated form exert a beneficial effect in reducing some disturbances associated with aging.
\end{abstract}

\section{Introduction}

Aging is a slow, irreversible, and cumulative process. Organisms with a high metabolic rate (increased oxygen consumption) had a shorter life span and that hyperbaric oxygen and radiation caused free radical oxygen damage to cells. When these reactive oxygen species are created by the metabolism inside cells, these free radical chemicals can damage vital cell components on contact, damage DNA, and impair cell processes. This free radical theory explained how aging could be a gradual yet cumulative process inside our cells, related to oxygen metabolism (Harman, 2009). Therefore, oxidative stress is a significant factor responsible for both the onset and the progression of several chronic diseases such as cardiovascular, neurodegenerative diseases and cancer. Plant foods contain many bioactive compounds able to counteract oxidative stress; there is much evidence confirming the fact that legume-rich food may 
significantly alter people's overall health and quality of life. Legumes provide powerful nutrition as well as proven anticancer, chemopreventive antioxidant and antimicrobial properties (Dixon, 2001).

Legumes contain several phenolic compounds, in addition to glutathione, soluble proteins, and tocopherols, which are considered to be natural antioxidants (Fernandez-Orozco et al., 2003). Among them, these non-phenolic antioxidant compounds may exert a synergistic effect, together with phenolic ones, which could be the origin of the differences in the antioxidant activity of different leguminous seeds. Moreover, legumes contain some bioactive peptides that can exert an antioxidant effect (Malaguti et al., 2014).

All over the world legumes are consumed after different types of processing (e.g., cooking, frying) but, the nutraceutical and nutritional quality improved significantly by sprouting. Legume sprouts are a good source of highly bioavailable proteins, starch, lipids and minerals. Additionally, germinated seeds contain significant amounts of polyphenols with well-documented pro-health properties (Gawlik-Dziki and S'wieca, 2011).). Moreover, studies on changes in antioxidant compounds and antioxidant capacity of legumes during different processing have also gained interest (Torres et al, 2007).

In addition legumes are low in fat, and rich in proteins, complex hydrocarbons, and minerals, they contain a rich variety of phytochemicals, including phytosterols, saponins, dietary fiber, polyphenols, protease inhibitors, and phytic acid and bioactive carbohydrates (Amarowicz and Pegg, 2008), which if consumed in sufficient quantities may help to reduce tumour risk (Mathers, 2002). Epidemiological and intervention studies indicated that legume consumption is inversely associated with the risk of coronary heart disease (Boualga et al.,2009), type II diabetes mellitus (Helmstädter, 2010) and obesity (Rizkalla et al.,2002).

The present study was designed to evaluate and compare the effect of feeding on five processed legumes (cooked and germinated) which are commonly used in Egyptian food like; faba bean, chickpea, lentil, white bean and fenugreek on the oxidative stress during aging in experimental rats. In addition, liver enzymes, lipid profile, hematological pattern and histopathological changes in liver was investigated.

\section{Material and methods}

\section{Materials:}

Legumes; faba bean (Vicia faba L.), white bean (Phaseolus vulgaris), chickpea( Cicer arietinum L.), lentil ( Lens culimaris) and fenugreek (Trigonella foenum-graecum L.) were grown during 2013 season, and obtained from the Field Crops Research Institute, Agricultural Research Center, Ministry of Agriculture and Land Reclamation, Giza, Egypt. 


\section{Egypt. J. of Nutrition and Health Vol. 10 No. 1 (2015)}

\section{Preparation of samples:}

Soaking: Legumes seeds were soaked in tap water in ratio $1: 3(\mathrm{w} / \mathrm{v})$ for 12 hours with the addition of $5 \mathrm{ml} / \mathrm{L}$ acetic acid (5\%). At the end of soaking period, the soaked water was discarded and rinsed twice in tap water. Half of soaked seeds were cooked and the other part was germinated.

Cooking: The soaked samples were subjected to cooking treatment by boiling in a covered stainless-steel pot and cooked on a moderate flame with enough water retention. For all cooking treatments, the minimum cooking time was used to reach a similar tenderness for an adequate palatability and taste according to the Egyptian eating habits.

Germination: After soaking the water was drained and the seed samples were allowed to germinate under a wet muslin cloth for $48 \mathrm{hrs}$.

The cooked and germinated materials were dried at $45 \pm 5^{\circ} \mathrm{C}$ under vacuum and ground in a laboratory mill to obtain fine flour and kept at $-18^{\circ} \mathrm{C}$ until analysis.

\section{Animals and treatments}

Sixty six female Sprague-Dawley rats aged 15-16 months old weighing $304 \pm 3 \mathrm{~g}$ (which is considered equivalent to the average age of menopause women is 51 years according to the American Medical Association, Durbin et al., 1966) were purchased from the Animal Department Laboratory, Research Institute of Ophthalmology, Giza, Egypt. The animals were housed in plastic cages, fed on basal diet (BD) that was based on AIN -93 G formulation with some modification (Reeves et al.,1993) and provided water ad libitum for one month as an adaptation period. The animal room was maintained at $21^{\circ} \mathrm{C} \pm 2^{\circ} \mathrm{C}$ with timed lighting $12 \mathrm{~h}$ and relative air humidity of $40 \%$ to $60 \%$.

After the adaptation period, the rats were randomly divided into 11 groups (each group contained 6 rats): the first group continued on basal diet feeding which represent the control group. The remaining 10 groups fed on the basal diets containing $20 \%$ of different tested legumes as shown in table (1). The BD supplemented with the different legumes was adjusted for protein, fat and fiber to have the same energy value as in basal diet (control). The experimental period continued for 8 weeks. During the experiment, water was allowed ad-libitum.

The body weight was recorded weekly. At the end of the experiment, the final body weights of rats were recorded, then the animals were anaesthetized by diethyl ether. The blood samples were collected from eye plexuses and divided into two patches. The first patch was collected into two heparinized tubes to obtain the whole blood, one of them subjected to measure the hematological profile immediately and the other subjected to prepare erythrocyte lysate as described by Yang et al. (2006). The second patch was collected in dry clean centrifuge tubes to prepare serum by leaving the samples for 15 minutes at room temperature, then the tubes were centrifuged for $15 \mathrm{~min}$ at $3000 \mathrm{rpm}$ and the clean supernatant serum was collected. The prepared erythrocyte lysate and serum samples were kept frozen at $-20^{\circ} \mathrm{C}$ until the time of analysis. The carcasses were dissected and the organs were cut off, washed in saline solution and weighed. Then, liver specimens were subjected for histological examination.

\section{Biochemical analyses}

Lipid profile; total cholesterol (TC), triglycerides (TG) and high-density lipoproteins cholesterol (HDL-C) were determined according to Stein(1986), Fossati and Prencipe (1982) and Assmann (1979), respectively. Low-density 
lipoprotein cholesterol (LDL-C) was determined by calculation using the following equation LDL-C = [TC-(HDLC+TG/5)] as described by Varley et al.(1980).Very low-density lipoproteins cholesterol (VLDL-C) was calculated according to Wallach (1992) using the following equation: (VLDL-C = serum triglycerides/5). Atherogenic index (AI) was calculated according to (Harnafi et al., 2009) by the following equation: AI = (S.LDL-C+S.VLDL- C)/ (S. HDL-C).

Superoxide dismutase (SOD) and glutathione peroxidase (GPX) enzymes were determined in erythrocyte lysate by enzymatic colorimetric procedures according to Dechatelet et al. (1974) and Rotruck et al. (1973), respectively. Moreover, serum lipid peroxidation (malondialdehyde, MDA) and total antioxidant capacity level were determined according to Ohkawa et al. (1979) and Koracevic et al. (2001), respectively.

Alanine amino transferase (ALT) and aspartate-amino transferase (AST) were determined according to the method described by Reitman and Frankel (1957). Serum alkaline phosphatase (ALP) was determined according to Varley et al. (1980). Serum total protein and albumin were determined according to Henry (1964) and Webster (1974), respectively. Serum globulin was calculated as follows: Serum Globulin = serum total protein - serum albumin (Varley et al., 1980).

Blood hemoglobin $(\mathrm{g} / \mathrm{dl}))$, hematocrit value $(\%)$, red blood cells $\left(x 10^{6} / \mu \mathrm{l}\right)$, white blood cells $\left(x 10^{3} / \mu \mathrm{l}\right)$ and platelets $\left(\times 10^{3} / \mu \mathrm{l}\right)$ were determined in whole blood by Coulter counter $\mathrm{M}_{4}(30)$ system according to the method of Moser et al.(2001)

\section{Postmortem and histopathological examination:}

Rats were subjected to postmortem examination to detect any abnormal gross changes. Tissue specimens from liver of rats were collected, fixed in $10 \%$ neutral buffered formalin, processed and embedded in Paraffin wax, sectioned at $4 \mu \mathrm{m}$ and stained with Hematoxylin and Eosin (Bancroft and Gamble, 2008) and examined under an Olympus microscope (Olympus, Japan).

\section{Statistical analysis:}

Statistical analyses were carried out by SPSS19 program. Data were expressed as means \pm SEM and the statistical analysis was performed using one-way analysis of variance followed by Duncan's tests according to (Snedecor and Cochran, 1989).

\section{Results}

\section{Body weight}

As shown in Table 2, after eight weeks of experimental period, no significant differences in final body weight in all tested groups except germinated white bean supplemented group which had the lowest value as compared with control group. Also, it could be noticed that cooking treatment caused increment in final body weight of rats more than germination treatment for all tested legumes. At the end of the experiment the weight change showed the highest percentage of decrease $(-7.7 \%)$ in group consumed diet including germinated white bean and the highest percentage of increase $(+7.1 \%)$ in cooked lentil supplemented diet group. As demonstrated in the same table, no significant changes occurred in relative organs weights among the tested groups. 


\section{Egypt. J. of Nutrition and Health Vol. 10 No. 1 (2015)}

\section{Lipids profile.}

Table (3) shows the lipid profile in the tested groups. In case of serum total cholesterol (TC) levels, there were significant decreases in all treated groups as compared with the control group. It could be noticed that the lowest decrease in (TC) relative to control group occurred in groups of germinated fenugreek, white bean and cooked fenugreek (23.8 \%, 23.5\% and $21 \%$, respectively). Also, there were significant increases in HDL-C levels in both of cooked faba bean and germinated lentil groups as compared to the control group. The levels of serum LDL-C showed a statistical decrement in tested groups except groups supplemented with cooked chickpea, white bean and fenugreek versus control group.

As shown in the same Table, feeding on diet contained the studied legumes led to a significant reduction in triglycerides (TG) and VLDL-C levels as compared to control group. The highest percentage decreases of $A I$ relative to control group were $46.5,44$ and $40 \%$ in groups supplemented with germinated lentil, cooked faba bean and germinated faba bean, respectively (Table 3 ).

\section{Antioxidant activity}

As mentioned in the table 4 , there are marked increments $(p \leq 0.05)$ of total antioxidant capacity in all treated groups except the cooked fenugreek group as compared to the control group. The lipid peroxidation level (malondialdehyde, MDA) decreased significantly in the experimental groups except both of cooked chickpea and fenugreek groups which exhibited non-significant decrement relative to control one. The activities of antioxidant enzymes SOD and GPx exhibited higher activity in treated groups particularly, germinated treatments with highest mean values obtained in germinated lentil group were $363.53(\mathrm{U} / \mathrm{Hb})$ and $374.33(\mathrm{mU} / \mathrm{ml})$, respectively .

\section{Liver function.}

As noticed in Table 5, feeding on diets containing germinated legumes caused reduction in activities of serum alkaline phosphatase (ALP) and aspartate transferase (AST) enzymes more than the cooking treatments. From the same table, it could be concluded that there was a statistical decrease of ALP activity in groups fed on diets supplemented with faba bean and fenugreek (cooked and germinated) relative to control group. Also, the levels of AST and ALT activities decreased significantly in all treated groups compared with the control group. The lowest values in germinated lentil group were 92.0 and $39.7(\mathrm{U} / \mathrm{L})$, respectively. The effect of different legumes inclusion in diet formulations on serum protein resulted in noticeable increases in groups fed germinated treatments relative to cooked legumes but there were no significant differences of serum albumin and globulin among the tested groups.

\section{Hematological profile.}

As shown in table 6, it could be concluded that no statistical differences in hematological parameters among the tested groups. However, feeding on germinated lentil supplemented diet recorded the highest values in $\mathrm{Hb}(15.20 \%)$ and hematocrit $(51.30 \%)$. 


\section{Histopathological findings:}

Histopathological findings of liver were recorded and scored according to their severity as shown in Table (7). In the control group there was diffuse vacuolar degeneration of hepatocytes and focal areas of hepatocellular coagulated necrosis. There was severe congestion in central veins, blood sinusoids and portal blood vessels. Concerning groups fed on faba bean either cooked or germinated, the number of hepatocytes that showed vacuolation and necrosis were fewer than in the control group, blood sinusoids were dilated and engorged with blood. Groups fed on Chickpea either cooked or germinated showed diffuse hepatocytic vacuolar degeneration, focal areas of hepatocellular coagulated necrosis and congestion in central veins but these changes were less than those in the control group,particularly in the germinated chickpea group.

In groups fed on Lentil either cooked or germinated, the number of hepatocytes that showed vacuolation were fewer than the control group, while there was no observable hepatocellular coagulative necrosis. Portal blood vessels were dilated and engorged with blood. Groups fed on white bean either cooked or germinated and germinated fenugreek seeds showed hepatocellular vacuolation and necrosis fewer in number than in control group. In addition, the diet contained cooked fenugreek did not affect the hepatocytic vacuolar degeneration numbers. There was congestion in central veins in either cooked or germinated white bean or fenugreek.

\section{Discussion}

Numerous studies have shown that oxidative stress contributes to the development and progression of chronic diseases such as cardiovascular diseases, diabetes, neurodegenerative diseases and cancer. Hence, ameliorating oxidative stress through treatment with antioxidants in plant foods such as legumes might be an effective strategy for prevention or reducing these diseases (Maria et al., 2007).

The current study showed that feeding on diets supplemented with cooked legumes caused higher body weight gain than germinated ones. This is in agreement with Vadivel et al. (2011) who explained that cooking legumes can reduce the anti-nutritional factors such as a-amylase and a-glucosidase inhibitors. $\alpha$-Amylase inhibitors are starch blockers, which can bind with the reactive sites of amylase enzyme and alter its catalytic activity, thus controlling the blood sugar level and $a$-glucosidase inhibitor can retard the rate of absorption of glucose through the intestine by competitive and reversible inhibition of intestinal a glucosidase enzyme. The highest percentage of decrease in body weight in group fed germinated white bean in our study may be attributed to the fact that white bean considered the best source of an a amylase inhibitor, known as phaseolamin that cause reduction in appetite and body weight and blood glucose in rats (Fantini et al., 2009).

Our study showed improvement in lipid profile, particularly VLDL-C and triglycerides levels as the result of feeding diet supplemented with legumes. Furthermore, cooked or germinated fenugreek supplemented diets showed a marked decrement in VLDL-C and triglycerides levels. This confirmed the results of Winham and Hutchins (2007) who indicated that daily intake of half a cup of baked bean in hypercholesterolemic adults can reduce serum TC by $-5.6 \%$ and serum LDL-C by $-5.4 \%$. Another study concluded that when twenty-six individuals with Peripheral artery disease (PAD) consumed $1 / 2$ cup/day of cooked mixed legumes (beans, peas, lentils, chickpeas) for 8 weeks, total and LDLcholesterol were reduced by $5.0 \%$ and $8.7 \%$, respectively (Zahradka et al., 2013). The anti-diabetic and hypolipidemic 


\section{Egypt. J. of Nutrition and Health Vol. 10 No. 1 (2015)}

activity of fenugreek may be attributed to soluble mucilage fiber, galactomannan as of the viscous property it has potential to reduce intestinal absorption of glucose and; therefore it has a benefit of blood glucose control (Srichamroen et al., 2008). The hypolipidemic effect of this mucilage may lead to a decrease in the synthesis and secretion of VLDL-C by hepatocytes. A reduction in production of VLDL-C can be due to a reduction in the synthesis of apo $B$ as well as lipids associated with VLDL-C (Sharma et al., 1990). The present study shows a significant reduction of Al (Atherogenic Index) values in rats fed diet contained both cooked and germinated faba bean and germinated lentil. This may be due to the fact that faba bean contains higher amount of phytoesterols compounds especially $\beta$-sitosterol and lentil contains higher value of flavonoids ( $1841.9 \mu \mathrm{g} / 100 \mathrm{~g}$ fresh weight) compared to other studied legumes (Kalogeropoulos et al., 2010). Phytosterols may be effective in reducing cholesterol absorption and in protection against low-density lipoprotein (LDL-C) oxidation (Andersson et al., 2004). Moreover, the potent antioxidant capacity of faba bean seeds largely contributed by the proanthcyanidins or highly polymerized tannins (Siah et al., 2012).

Our study revealed that germination process is more effective than cooking treatment by enhancing the antioxidant enzymes SOD and GPx. This is consistent with Doblado et al. (2007) who suggested that biotechnological treatments such as germination and fermentation increased the content of specific flavonoids including resveratrol and enhanced the antioxidant capacity of legumes using different experimental models. Nevertheless, the beneficial properties of legumes can be reduced by widely used thermal treatments such as conventional boiling, conventional steaming, pressure cooking, or pressure steaming. Such treatments significantly decreased the total phenolic, procyanidin, saponin, and phytic acid content of cool-season food legumes, thus decreasing their cellular antioxidant and antiproliferative activities. Lentil either cooked or germinated exhibited higher values of superoxide dismutase enzyme and glutathione peroxidase activities relative to other studied legumes in the current study. This desirable effect of lentil could be explained by the fact that lentil contains higher value of flavonoids content (1841.9 $\mu \mathrm{g} / 100 \mathrm{~g}$ fresh weight) compared to other studied legumes (Kalogeropoulos et al., 2010). Also, germinated lentil had the highest content of folate as compared to the other tested legumes (Salem et al., 2014) which may act as a direct antioxidant and reduces the superoxide radicals or improve the cellular antioxidant defense systems (Doshi et al., 2002).

Aminotransferases (AST and ALT) mediate the catalysis of amino-transfer reactions and they are markers for clinical diagnosis of liver injury $(\mathrm{Li}, \mathbf{2 0 0 7 )}$, while ALP is responsible for removing phosphate group from nucleotides and proteins and also used as a marker of hepatic functions (Yoo et al., 2008).As revealed in the present study, germination of legumes is more effective in reduction of serum ALP and AST activities than cooking process, also lentil (germinated) supplemented diet exerted the lowest levels of serum ALT and AST activities. In the present study, the lipid peroxidation and serum MDA level increased in control aged rats led to hepatic tissues damage and leakage of hepatic enzymes into the blood circulation (Ademiluyi and Oboh, 2012).

After feeding diets supplemented with legumes there were improvement in histopathological lesions appeared as the number of hepatocytes that showed vacuolation, necrosis and congestion of blood vessels were fewer than those in control group, particularly in group fed lentil containing diet. This may be explained by Shimoda et al. (2008) who suggested that formulated diets containing germinated legumes are rich in antioxidants such as polyphenols with hepatoprotective properties. Also, germination process caused increment of protein digestibility, degradation of the high molecular weight protein to low molecular weight protein, simple peptides and amino acids which act as power antioxidants against free radicals scavenging activities and hepatoprotective agents (Je et al., 2007). On other hand, 
lentils are also good sources of phenolic and non-phenolic antioxidants as catechins and procyanidins. Total antioxidant measurements for lentil seeds were reported to be significantly higher than those of other legumes (Xu and Chang, 2008) and (Oomah et al., 2011).

The increment of serum protein in rats fed germinated legumes supplemented diets relative to control may be due to increased protein catabolism or increased lipid peroxidation which led to formation of protein- malondialdhyde adducts in control aged rats. Contrary, in rats fed germinated legume supplemented diets, the hepatoprotective properties of their polyphenol constituents and also availability of their amino acids may led to improvement of serum protein (Ademiluyi and Oboh, 2012).

Feeding diets containing different legumes did not affect the hematological parameters significantly as compared to control. These results may be explained by the fact that iron from plant sources is less easily absorbed than the heme-bound iron of animal sources. However, , germinated lentil supplemented diet recorded the highest values in $\mathrm{Hb}$, hematocrit value and RBCs count may be attributed to the fact that germinated lentil had the highest content of folic acid as compared to the other tested legumes (Salem et al., 2014) which cause enhancement of hemopoietic organs and erythropoiesis.

\section{Conclusion}

Although consumers often view legumes as an alternate inexpensive protein, few are aware of the potential health benefits from legume consumption or their role as a functional food. Implementation of dietary changes that include increased consumption of legumes known to reduce risk of several diseases is realistic and cost effective in comparison with other more traditional interventions, namely, drug therapy, especially for individuals in the borderline rather than high-risk categories. Egyptian habits limited the germination process to usual legumes such as broad bean and fenugreek, therefore our study focus attention on germination may be extended to other legumes like, lentil and chickpea. Also, it is recommended that the diversity among the different legumes consumption because each one is complementary to other to obtain the maximum benefit. 
Egypt. J. of Nutrition and Health Vol. 10 No. 1 (2015)

Table (1):

The experimental diets of rats.

\begin{tabular}{|c|c|c|c|c|c|c|c|c|c|c|c|}
\hline Ingredients & $\begin{array}{l}\text { 윽 } \\
\text { 인 }\end{array}$ & $\begin{array}{l}\text { N } \\
\text { 윽 } \\
\text { 인 }\end{array}$ & $\begin{array}{l}\text { m } \\
\text { 윽 } \\
\text { 윰 }\end{array}$ & $\begin{array}{l}\text { 寸 } \\
\text { 윽 } \\
\text { 인 }\end{array}$ & $\begin{array}{l}\text { م) } \\
\text { 윽 } \\
\text { 인 }\end{array}$ & $\begin{array}{l}0 \\
\text { 윽 } \\
\text { 인 }\end{array}$ & $\begin{array}{l}\text { 슥 } \\
\text { 윽 } \\
\text { 仓ั }\end{array}$ & $\begin{array}{l}\infty \\
\text { 윽 } \\
\text { 인 }\end{array}$ & $\begin{array}{l}\text { の } \\
\text { 윽 } \\
\text { 인 }\end{array}$ & $\begin{array}{l}\text { 음 } \\
\text { 인으 }\end{array}$ & $\frac{0}{3}=$ \\
\hline Casein* & 14 & 9.94 & 8.59 & 10.04 & 8.50 & 8.21 & 7.33 & 7.72 & 6.70 & 9.49 & 8.27 \\
\hline Corn oil & 5 & 4.61 & 4.63 & 4.12 & 4.20 & 4.86 & 4.86 & 4.80 & 4.83 & 3.76 & 3.85 \\
\hline Vitamin mix. & 1 & 1 & 1 & 1 & 1 & 1 & 1 & 1 & 1 & 1 & 1 \\
\hline Salt mix. & 3.5 & 3.5 & 3.5 & 3.5 & 3.5 & 3.5 & 3.5 & 3.5 & 3.5 & 3.5 & 3.5 \\
\hline Choline chloride & 0.2 & 0.2 & 0.2 & 0.2 & 0.2 & 0.2 & 0.2 & 0.2 & 0.2 & 0.2 & 0.2 \\
\hline Fiber & 5 & 3.49 & 3.28 & 4.07 & 3.94 & 4.01 & 3.60 & 3.68 & 3.39 & 3.56 & 2.98 \\
\hline Starch & 71.30 & 57.26 & 58.80 & 57.07 & 58.66 & 58.22 & 59.51 & 59.10 & 60.38 & 58.49 & 60.20 \\
\hline Cooked faba bean & -- & 20 & -- & - & -- & -- & - & -- & -- & -- & -- \\
\hline Germinated faba bean & - & -- & 20 & -- & -- & - & - & -- & - & - & -- \\
\hline Cooked chickpea & -- & -- & -- & 20 & - & - & -- & -- & - & -- & -- \\
\hline Germinated chickpea & -- & -- & -- & -- & 20 & -- & -- & -- & -- & -- & -- \\
\hline Cooked lentil & -- & -- & -- & -- & -- & 20 & -- & -- & -- & -- & -- \\
\hline Germinated lentil & -- & -- & -- & -- & -- & -- & 20 & -- & -- & -- & -- \\
\hline Cooked white bean & -- & -- & -- & -- & -- & -- & -- & 20 & -- & - & -- \\
\hline Germinated white bean & -- & -- & - & -- & -- & - & -- & -- & 20 & - & -- \\
\hline Cooked fenugreek & -- & -- & - & -- & -- & - & - & -- & -- & 20 & -- \\
\hline Germinated fenugreek & -- & -- & -- & -- & -- & -- & -- & -- & -- & -- & 20 \\
\hline
\end{tabular}


Table (2):

Effect of experimental diets on body weights and relative organ weights

\begin{tabular}{|c|c|c|c|c|c|c|c|}
\hline \multirow[b]{2}{*}{ Groups } & \multirow[b]{2}{*}{$\begin{array}{l}\text { Initial body } \\
\text { weight (g) }\end{array}$} & \multirow[b]{2}{*}{$\begin{array}{r}\text { Final body } \\
\text { weight (g) }\end{array}$} & \multirow{2}{*}{$\begin{array}{l}\text { Percentage } \\
\text { change of } \\
\text { body } \\
\text { weight gain } \\
(\%)\end{array}$} & \multicolumn{4}{|c|}{ Relative organs weights (\%) } \\
\hline & & & & Liver & Brain & Heart & Spleen \\
\hline $\begin{array}{l}\text { Control } \\
\text { Faba bean }\end{array}$ & & $306.00 \pm 3.79^{\text {bcd }}$ & +0.66 & $2.32 \pm 0.18^{\mathrm{ab}}$ & $0.41 \pm 0.03^{a}$ & $0.29 \pm 0.03^{b c}$ & $0.19 \pm 0.03^{\mathrm{abc}}$ \\
\hline Cooked & $304.00 \pm 5.61^{a}$ & $318.33 \pm 6.32^{\mathrm{abcd}}$ & +4.7 & $1.75 \pm 0.13^{b}$ & $0.47 \pm 0.03^{a}$ & $0.28 \pm 0.03^{b c}$ & $0.17 \pm 0.01^{\mathrm{abc}}$ \\
\hline $\begin{array}{l}\text { Germinated } \\
\text { Chickpea }\end{array}$ & $304.00 \pm 4.12^{\mathrm{a}}$ & $310.33 \pm 5.35^{\mathrm{bcd}}$ & +2.1 & $1.94 \pm 0.11^{b}$ & $0.43 \pm 0.01^{a}$ & $0.32 \pm 0.01^{\mathrm{ab}}$ & $0.20 \pm 0.02^{\mathrm{abc}}$ \\
\hline Cooked & $304.00 \pm 3.27^{\mathrm{a}}$ & $324.33 \pm 4.31^{\mathrm{ab}}$ & +6.4 & $2.05 \pm 0.15^{\mathrm{ab}}$ & $0.45 \pm 0.06^{a}$ & $0.22 \pm 0.04^{\mathrm{cd}}$ & $0.17 \pm 0.01^{\mathrm{abc}}$ \\
\hline $\begin{array}{l}\text { Germinated } \\
\text { Lentil }\end{array}$ & $303.80 \pm 4.75^{\mathrm{a}}$ & $313.33 \pm 2.91^{\mathrm{bcd}}$ & +3.1 & $2.10 \pm 0.19^{a b}$ & $0.49 \pm 0.01^{a}$ & $0.27 \pm 0.03^{\mathrm{bcd}}$ & $0.21 \pm 0.02^{\mathrm{ab}}$ \\
\hline Cooked & $304.20 \pm 4.63^{\mathrm{a}}$ & $325.67 \pm 6.96^{\mathrm{ab}}$ & +7.1 & $1.98 \pm 0.16^{b}$ & $0.42 \pm 0.04^{a}$ & $0.23 \pm 0.02^{\mathrm{cd}}$ & $0.14 \pm 0.02^{c}$ \\
\hline $\begin{array}{l}\text { Germinated } \\
\text { White bean }\end{array}$ & $304.40 \pm 3.87^{\mathrm{a}}$ & $320.67 \pm 3.18^{\mathrm{abcd}}$ & +5.3 & $2.02 \pm 0.18^{b}$ & $0.45 \pm 0.06^{a}$ & $0.22 \pm 0.02^{c d}$ & $0.16 \pm 0.01^{\mathrm{bc}}$ \\
\hline Cooked & $304.40 \pm 5.37^{\mathrm{a}}$ & $302.33 \pm 6.36^{\mathrm{bcd}}$ & -0.68 & $2.16 \pm 0.11^{\mathrm{ab}}$ & $0.48 \pm 0.02^{a}$ & $0.32 \pm 0.03^{\mathrm{ab}}$ & $0.20 \pm 0.02^{\mathrm{abc}}$ \\
\hline $\begin{array}{l}\text { Germinated } \\
\text { Fenugreek }\end{array}$ & $303.80 \pm 5.41^{\mathrm{a}}$ & $280.33 \pm 3.33^{\mathrm{e}}$ & -7.7 & $2.60 \pm 0.20^{a}$ & $0.46 \pm 0.01^{a}$ & $0.33 \pm 0.03^{\mathrm{ab}}$ & $0.19 \pm 0.02^{\mathrm{abc}}$ \\
\hline Cooked & $304.20 \pm 4.14^{a}$ & $323.33 \pm 1.07^{\mathrm{abc}}$ & +6.2 & $2.19 \pm 0.17^{\mathrm{ab}}$ & $0.42 \pm 0.02^{a}$ & $0.29 \pm 0.01^{b c}$ & $0.15 \pm 0.02^{b c}$ \\
\hline Germinated & $304.20 \pm 5.20^{a}$ & $310.00 \pm 5.66^{\mathrm{bcd}}$ & +1.9 & $2.10 \pm 0.23^{\mathrm{ab}}$ & $0.48 \pm 0.02^{a}$ & $0.26 \pm 0.03^{b c d}$ & $0.22 \pm 0.03^{a}$ \\
\hline
\end{tabular}

Each value represents the mean $\pm \mathrm{SE}$. The mean values with different superscript alphabets indicate significant differences $(P \leq 0.05)$.

${ }^{\star}$ The relative organ weight $=($ weight of organ/total body weight $) \times 100$. 
Table (3):

Effect of experimental diets on lipids profile

\begin{tabular}{|c|c|c|c|c|c|c|}
\hline Groups & $\begin{array}{l}\text { T.C } \\
(\mathrm{mg} / \mathrm{dl})\end{array}$ & HDL-C (mg/dl) & LDL-C (mg/dl) & VLDL-C (mg/dl) & $\begin{array}{l}\text { T.G } \\
(\mathrm{mg} / \mathrm{dl})\end{array}$ & Al \\
\hline $\begin{array}{l}\text { Control } \\
\text { Faba bean }\end{array}$ & $97.97 \pm 2.27^{a}$ & $49.19 \pm 1.36^{\mathrm{cd}}$ & $25.80 \pm 1.15^{b}$ & $22.98 \pm 0.06^{a}$ & $114.90 \pm 0.31^{a}$ & $0.99 \pm 0.06^{\mathrm{abc}}$ \\
\hline Cooked & $85.94 \pm 1.62^{b c}$ & $55.27 \pm 2.08^{\mathrm{ab}}$ & $15.37 \pm 0.58^{e}$ & $15.30 \pm 0.32^{f}$ & $76.50 \pm 1.59^{f}$ & $0.55 \pm 0.07^{\mathrm{ef}}$ \\
\hline $\begin{array}{l}\text { Germinated } \\
\text { Chickpea }\end{array}$ & $83.37 \pm 2.82^{c}$ & $52.11 \pm 1.92^{\mathrm{bc}}$ & $9.69 \pm 0.64^{f}$ & $21.57 \pm 0.54^{b}$ & $107.80 \pm 2.71^{b}$ & $0.59 \pm 0.06^{\mathrm{ef}}$ \\
\hline Cooked & $91.01 \pm 1.94^{b}$ & $45.13 \pm 2.47^{d}$ & $26.76 \pm 1.01^{\mathrm{ab}}$ & $19.12 \pm 0.13^{d}$ & $95.60 \pm 0.65^{d}$ & $1.01 \pm 0.07^{\mathrm{ab}}$ \\
\hline $\begin{array}{l}\text { Germinated } \\
\text { Lentil }\end{array}$ & $83.19 \pm 1.76^{c}$ & $47.06 \pm 0.67^{\mathrm{cd}}$ & $19.51 \pm 1.15^{d}$ & $16.62 \pm 0.56^{e}$ & $83.11 \pm 2.81^{\mathrm{e}}$ & $0.76 \pm 0.07^{\text {cde }}$ \\
\hline Cooked & $90.16 \pm 1.22^{b}$ & $52.00 \pm 1.86^{\mathrm{bc}}$ & $19.47 \pm 0.78^{d}$ & $18.69 \pm 0.10^{d}$ & $93.48 \pm 0.50^{d}$ & $0.73 \pm 0.06^{\text {def }}$ \\
\hline $\begin{array}{l}\text { Germinated } \\
\text { White bean }\end{array}$ & $88.83 \pm 1.27^{\mathrm{bc}}$ & $57.93 \pm 0.41^{a}$ & $10.21 \pm 0.58^{f}$ & $20.69 \pm 0.17^{c}$ & $103.49 \pm 0.85^{c}$ & $0.53 \pm 0.07^{f}$ \\
\hline Cooked & $89.44 \pm 1.37^{b}$ & $47.50 \pm 0.64^{c d}$ & $26.21 \pm 0.52^{\mathrm{ab}}$ & $15.74 \pm 0.19^{f}$ & $78.73 \pm 0.95^{f}$ & $0.88 \pm 0.08^{\mathrm{bcd}}$ \\
\hline $\begin{array}{l}\text { Germinated } \\
\text { Fenugreek }\end{array}$ & $74.95 \pm 2.04^{d}$ & $35.20 \pm 0.42^{\mathrm{e}}$ & $22.57 \pm 0.59^{c}$ & $17.18 \pm 0.16^{\mathrm{e}}$ & $85.91 \pm 0.81^{e}$ & $1.13 \pm 0.07^{\mathrm{a}}$ \\
\hline Cooked & $77.30 \pm 2.44^{d}$ & $36.96 \pm 2.55^{\mathrm{e}}$ & $25.42 \pm 1.39^{b}$ & $14.91 \pm 0.31^{f}$ & $74.58 \pm 1.53^{f}$ & $1.09 \pm 0.06^{a b}$ \\
\hline Germinated & $74.65 \pm 1.80^{d}$ & $39.00 \pm 2.08^{\mathrm{e}}$ & $22.25 \pm 1.15^{c}$ & $13.40 \pm 0.21^{9}$ & $67.00 \pm 1.06^{9}$ & $0.91 \pm 0.04^{\mathrm{abcd}}$ \\
\hline
\end{tabular}

Each value represents the mean \pm SE. The mean values with different superscript alphabets indicate significant differences $(P \leq 0.05)$ 
Table (4):

Effect of experimental diets on total antioxidant capacity and antioxidant enzymes

\begin{tabular}{|c|c|c|c|c|}
\hline Groups & $\begin{array}{l}\text { Total antioxidant } \\
\text { capacity (mM/L) }\end{array}$ & $\begin{array}{l}\text { MDA } \\
\text { (nmole/ml) }\end{array}$ & $\begin{array}{l}\text { SOD } \\
(\mathrm{U} / \mathrm{g} \mathrm{Hb})\end{array}$ & $\begin{array}{l}\text { GPx } \\
(\mathrm{mU} / \mathrm{ml})\end{array}$ \\
\hline $\begin{array}{l}\text { Control } \\
\text { Faba bean }\end{array}$ & $1.80 \pm 0.05^{c}$ & $3.99 \pm 0.29^{a}$ & $163.23 \pm 0.84^{n}$ & $285.67 \pm 2.91^{h}$ \\
\hline Cooked & $2.52 \pm 0.19^{b}$ & $2.47 \pm 0.16^{c}$ & $234.07 \pm 2.84^{\dagger}$ & $320.67 \pm 2.60^{\mathrm{et}}$ \\
\hline $\begin{array}{l}\text { Germinated } \\
\text { Chickpea }\end{array}$ & $2.75 \pm 0.13^{\mathrm{ab}}$ & $3.04 \pm 0.17^{\mathrm{bc}}$ & $244.44 \pm 1.94^{\mathrm{e}}$ & $336.33 \pm 4.33^{\mathrm{cd}}$ \\
\hline Cooked & $2.85 \pm 0.01^{\mathrm{ab}}$ & $3.13 \pm 0.41^{\mathrm{abc}}$ & $267.66 \pm 1.34^{d}$ & $328.67 \pm 3.76^{\mathrm{de}}$ \\
\hline $\begin{array}{l}\text { Germinated } \\
\text { Lentil }\end{array}$ & $2.69 \pm 0.02^{\mathrm{ab}}$ & $3.01 \pm 0.2^{b c}$ & $301.73 \pm 3.64^{c}$ & $348.67 \pm 3.53^{b}$ \\
\hline Cooked & $2.80 \pm 0.13^{\mathrm{ab}}$ & $3.05 \pm 0.16^{b c}$ & $337.08 \pm 2.35^{\mathrm{b}}$ & $346.00 \pm 2.08^{\mathrm{bc}}$ \\
\hline $\begin{array}{l}\text { Germinated } \\
\text { White bean }\end{array}$ & $2.74 \pm 0.06^{\mathrm{ab}}$ & $2.64 \pm 0.09^{b c}$ & $363.53 \pm 1.73^{a}$ & $374.33 \pm 5.70^{a}$ \\
\hline Cooked & $2.74 \pm 0.13^{\mathrm{ab}}$ & $2.94 \pm 0.23^{b c}$ & $159.05 \pm 0.99^{n}$ & $283.33 \pm 3.84^{n}$ \\
\hline $\begin{array}{l}\text { Germinated } \\
\text { Fenugreek }\end{array}$ & $2.91 \pm 0.03^{a}$ & $2.97 \pm 0.33^{b c}$ & $206.39 \pm 3.07^{9}$ & $305.33 \pm 3.76^{9}$ \\
\hline Cooked & $2.01 \pm 0.08^{c}$ & $3.33 \pm 0.55^{a b c}$ & $160.51 \pm 1.96^{n}$ & $290.67 \pm 4.41^{n}$ \\
\hline Germinated & $2.76 \pm 0.08^{a b}$ & $3.03 \pm 0.06^{b c}$ & $230.49 \pm 2.06^{\dagger}$ & $311.33 \pm 4.91^{\mathrm{tg}}$ \\
\hline
\end{tabular}

Each value represents the mean \pm SE. The mean values with different superscript alphabets indicate significant differences $(P \leq 0.05)$. 
Table (5):

Effect of experimental diets on Liver functions

\begin{tabular}{|c|c|c|c|c|c|c|}
\hline Groups & $\begin{array}{l}\text { ALP } \\
\text { (IU/L) }\end{array}$ & $\begin{array}{l}\text { AST } \\
(U / L)\end{array}$ & $\begin{array}{l}\text { ALT } \\
(U / L)\end{array}$ & $\begin{array}{l}\text { Total protein } \\
(\mathrm{g} / \mathrm{dL})\end{array}$ & $\begin{array}{l}\text { Albumin } \\
\text { (g/dL) }\end{array}$ & $\begin{array}{l}\text { Globulin } \\
\text { (g/dL) }\end{array}$ \\
\hline $\begin{array}{l}\text { Control } \\
\text { Faba bean }\end{array}$ & $194.12 \pm 2.99^{\mathrm{a}}$ & $114.87 \pm 0.71^{a}$ & $69.50 \pm 0.58^{a}$ & $5.75 \pm 0.08^{\mathrm{de}}$ & $3.70 \pm 0.20^{\mathrm{ab}}$ & $2.05 \pm 0.16^{\text {bcd }}$ \\
\hline Cooked & $165.63 \pm 2.43^{c d}$ & $103.07 \pm 0.87^{d}$ & $51.37 \pm 2.31^{\mathrm{cd}}$ & $5.69 \pm 0.60^{d e}$ & $3.70 \pm 0.20^{\mathrm{ab}}$ & $1.99 \pm 0.77^{\mathrm{bcd}}$ \\
\hline $\begin{array}{l}\text { Germinated } \\
\text { Chickpea }\end{array}$ & $160.55 \pm 2.42^{d}$ & $98.60 \pm 1.22^{\mathrm{e}}$ & $65.00 \pm 0.98^{b}$ & $6.29 \pm 0.11^{c d}$ & $4.06 \pm 0.25^{\mathrm{ab}}$ & $2.23 \pm 0.27^{\mathrm{bcd}}$ \\
\hline Cooked & $188.35 \pm 5.33^{a}$ & $99.73 \pm 1.01^{e}$ & $52.27 \pm 1.15^{\mathrm{cd}}$ & $6.19 \pm 0.22^{c d}$ & $4.15 \pm 0.02^{\mathrm{ab}}$ & $2.05 \pm 0.22^{\mathrm{bcd}}$ \\
\hline$\underline{\text { Germinated }}$ & $181.66 \pm 4.40^{\mathrm{ab}}$ & $93.53 \pm 0.29^{f g}$ & $46.87 \pm 0.58^{\text {ef }}$ & $7.40 \pm 0.09^{a}$ & $4.25 \pm 0.13^{a}$ & $3.15 \pm 0.17^{\mathrm{ab}}$ \\
\hline Cooked & $183.51 \pm 5.90^{\mathrm{ab}}$ & $112.07 \pm 0.66^{b}$ & $40.50 \pm 0.61^{g}$ & $5.67 \pm 0.07^{\mathrm{de}}$ & $3.87 \pm 0.11^{a b}$ & $1.80 \pm 0.17^{\mathrm{cd}}$ \\
\hline$\frac{\text { Germinated }}{\text { White bean }}$ & $179.73 \pm 5.53^{\mathrm{abc}}$ & $92.00 \pm 0.35^{9}$ & $39.70 \pm 0.15^{9}$ & $6.82 \pm 0.13^{\mathrm{abc}}$ & $4.22 \pm 0.11^{a}$ & $2.60 \pm 0.10^{\mathrm{abc}}$ \\
\hline Cooked & $184.33 \pm 7.21^{\mathrm{ab}}$ & $111.67 \pm 0.35^{b}$ & $53.30 \pm 0.46^{c}$ & $5.31 \pm 0.16^{e}$ & $3.87 \pm 0.19^{\mathrm{ab}}$ & $1.44 \pm 0.33^{d}$ \\
\hline$\frac{\text { Germinated }}{\text { Fenugreek }}$ & $182.35 \pm 4.09^{\mathrm{ab}}$ & $93.93 \pm 0.47^{\mathrm{fg}}$ & $62.90 \pm 0.58^{b}$ & $5.78 \pm 0.09^{d e}$ & $3.60 \pm 0.21^{b}$ & $2.18 \pm 0.26^{b c d}$ \\
\hline Cooked & $172.30 \pm 3.95^{\mathrm{bcd}}$ & $107.00 \pm 0.35^{c}$ & $44.70 \pm 0.58^{f}$ & $5.62 \pm 0.09^{\mathrm{de}}$ & $4.16 \pm 0.01^{a b}$ & $1.46 \pm 0.08^{d}$ \\
\hline$\underline{\text { Germinated }}$ & $170.38 \pm 3.22^{\mathrm{bcd}}$ & $95.53 \pm 1.67^{f}$ & $49.63 \pm 0.97^{\text {de }}$ & $6.91 \pm 0.10^{\mathrm{ab}}$ & $3.99 \pm 0.20^{\mathrm{ab}}$ & $2.92 \pm 0.15^{\mathrm{ab}}$ \\
\hline
\end{tabular}

Each value represents the mean \pm SE. The mean values with different superscript alphabets indicate significant differences $(P \leq 0.05)$. 
Table (6):

Effect of experimental diets hematological profile

\begin{tabular}{|c|c|c|c|c|c|}
\hline Groups & $\begin{array}{l}\text { Hemoglobin } \\
(\mathrm{g} / \mathrm{dl})\end{array}$ & $\begin{array}{l}\text { Hematocrit } \\
(\%)\end{array}$ & $\mathrm{RBC} \times 10^{6} / \mu \mathrm{l}$ & WBC $\times 10^{3} / \mu \mathrm{l}$ & Platelets $\times 10^{3} / \mu 1$ \\
\hline $\begin{array}{l}\text { Control } \\
\text { Faba bean }\end{array}$ & $14.20 \pm 0.46^{\mathrm{ab}}$ & $46.70 \pm 2.41^{a b}$ & $7.71 \pm 0.48^{a}$ & $13.43 \pm 1.39^{\mathrm{abc}}$ & $1013.34 \pm 1.86^{\mathrm{ab}}$ \\
\hline Cooked & $14.03 \pm 0.44^{\mathrm{ab}}$ & $47.53 \pm 1.82^{a b}$ & $7.93 \pm 0.37^{a}$ & $15.10 \pm 1.04^{\mathrm{ab}}$ & $1011.31 \pm 0.88^{\mathrm{ab}}$ \\
\hline $\begin{array}{l}\text { Germinated } \\
\text { Chickpea }\end{array}$ & $13.80 \pm 0.26^{a b c}$ & $45.33 \pm 1.50^{\mathrm{ab}}$ & $7.64 \pm 0.36^{a}$ & $10.43 \pm 0.93^{\mathrm{abc}}$ & $1011.67 \pm 1.67^{\mathrm{ab}}$ \\
\hline Cooked & $13.53 \pm 0.63^{\mathrm{abc}}$ & $46.23 \pm 1.85^{\mathrm{ab}}$ & $7.49 \pm 0.49^{a}$ & $13.23 \pm 1.19^{\mathrm{abc}}$ & $1012.65 \pm 0.88^{a b}$ \\
\hline $\begin{array}{l}\text { Germinated } \\
\text { Lentil }\end{array}$ & $14.27 \pm 0.13^{\mathrm{ab}}$ & $48.17 \pm 0.35^{\mathrm{ab}}$ & $8.01 \pm 0.13^{a}$ & $12.40 \pm 2.46^{\mathrm{abc}}$ & $1014.68 \pm 1.45^{a}$ \\
\hline Cooked & $13.83 \pm 0.14^{\mathrm{abc}}$ & $45.63 \pm 0.65^{a b}$ & $7.80 \pm 0.14^{a}$ & $10.30 \pm 0.85^{b c}$ & $1015.33 \pm 0.32^{a}$ \\
\hline $\begin{array}{l}\text { Germinated } \\
\text { White bean }\end{array}$ & $15.20 \pm 0.64^{a}$ & $51.30 \pm 2.08^{a}$ & $8.41 \pm 0.65^{a}$ & $13.63 \pm 2.98^{\mathrm{abc}}$ & $1014.67 \pm 2.60^{a}$ \\
\hline Cooked & $13.83 \pm 0.33^{\mathrm{abc}}$ & $45.67 \pm 1.60^{\mathrm{ab}}$ & $7.67 \pm 0.12^{a}$ & $15.40 \pm 2.92^{\mathrm{ab}}$ & $1012.35 \pm 1.20^{\mathrm{ab}}$ \\
\hline $\begin{array}{l}\text { Germinated } \\
\text { Fenugreek }\end{array}$ & $13.29 \pm 0.29^{b c}$ & $43.13 \pm 0.18^{b}$ & $7.37 \pm 0.13^{a}$ & $12.63 \pm 1.12^{a b c}$ & $1011.67 \pm 4.41^{\mathrm{ab}}$ \\
\hline Cooked & $13.30 \pm 0.29^{b c}$ & $45.37 \pm 1.24^{\mathrm{ab}}$ & $7.44 \pm 0.14^{a}$ & $12.47 \pm 1.69^{\mathrm{abc}}$ & $1011.33 \pm 0.86^{a b}$ \\
\hline Germinated & $14.07 \pm 0.32^{\mathrm{ab}}$ & $46.30 \pm 0.61^{\mathrm{ab}}$ & $7.70 \pm 0.17^{a}$ & $12.17 \pm 1.29^{\mathrm{abc}}$ & $1008.00 \pm 1.10^{b}$ \\
\hline
\end{tabular}

Each value represents the mean \pm SE. The mean values with different superscript alphabets indicate significant differences $(P \leq 0.05)$. 
Table (7):

Severity of recorded histopathological lesions of liver in tested groups

\begin{tabular}{|c|c|c|c|}
\hline Groups & $\begin{array}{l}\text { Vacuolar degeneration of } \\
\text { hepatocytes }\end{array}$ & $\begin{array}{l}\text { Hepatocellular } \\
\text { necrosis }\end{array}$ & $\begin{array}{l}\text { Congestion of hepatic } \\
\text { blood vessels }\end{array}$ \\
\hline $\begin{array}{l}\text { Control } \\
\text { Faba bean }\end{array}$ & +++ & +++ & +++ \\
\hline Cooked & ++ & ++ & + \\
\hline $\begin{array}{l}\text { Germinated } \\
\text { Chickpea }\end{array}$ & ++ & ++ & + \\
\hline Cooked & +++ & ++ & + \\
\hline $\begin{array}{l}\text { Germinated } \\
\underline{\text { Lentil }}\end{array}$ & ++ & + & ++ \\
\hline Cooked & ++ & - & + \\
\hline $\begin{array}{l}\text { Germinated } \\
\text { White bean }\end{array}$ & ++ & - & + \\
\hline Cooked & ++ & + & + \\
\hline $\begin{array}{l}\text { Germinated } \\
\text { Fenugreek }\end{array}$ & ++ & ++ & + \\
\hline Cooked & +++ & ++ & + \\
\hline Germinated & ++ & ++ & + \\
\hline
\end{tabular}




\section{References}

Ademiluyi A.O and Oboh G. (2012).

Attenuation of oxidative stress and hepatic damage by some fermented tropical legume condiment diets in streptozotozin-induced diabetes in rats. Asian Pacific J. of Tropical Medicine, 692-697.

Amarowicz R. and Pegg R.B. (2008).

Legumes as a source of natural antioxidants. European Journal of Lipid Science and Technology, 110: 865878.

Andersson S.W, Skinner J., Ellegard L., Welch A.A., Bingham A., Mulligan A., Andersson H.and Khaw K. (2004). Intake of dietary plant sterols is inversely related to serum cholesterol concentration in men and women in the EPIC Norfolk population: A cross-sectional study. Euro. J. Clin. Nutr. 58, 1378-1385.

Assmann G. (1979).

Cholesterol determination in high density lipoproteins separated by three different methods. Internist. 20: 559 604.

Bancroft J.D. and Gamble M. (2008).

Theory and Practice of Histopathological Techniques. 6th edition, Churchill Livingstone. New York, London and Madrid.

Boualga A., Prost J., Taleb-Senouci D., Krouf D., Kharoubi O., Lamri-Senhadji M., Belleville J.and Bouchenak M.(2009).

Purified chickpea or lentil proteins impair VLDL metabolism and lipoprotein lipase activity in epididymal fat, but not in muscle, compared to casein, in growing rats. Eur J Nutr, 48: 162-169.

Dechatelet L.R., Mc Call C.E., Mc Phial L.C. and Johnston R. B. (1974).

Superoxide dismutase activity in leukocytes. J. Clin. Invest. 53:1197-1201.

Dixon R. A. (2001).

Natural products and plant disease resistance. Nature, 411:843-847.

Doblado R., Frias J. and Vidal-Valverde C. (2007).

Changes in vitamin C content and antioxidant capacity of raw and germinated cowpea (Vigna sinensis var.carrilla) seeds induced by high pressure treatment. Food Chem. 101 (3): 918-923.

Doshi S.N., Jan F.W.,Stuart J.M.,Hilary J.D.,Malcolm J.I.and Jonathan G.(2002).

Folic acid improves endothelial function in coronary artery disease via mechanisms largely independent of homocysteine lowering.Circulation, 105: 22-26. 
Egypt. J. of Nutrition and Health Vol. 10 No. 1 (2015)

Durbin P.W, Williams M.H, Jeung N., Arnold J.S. (1966).

Development of spontaneous mammary tumors over the life-span of the female Charles River (SpragueDawley) rat: The influence of ovariectomy, thyroidectomy, and adrenalectomy-ovariectomy. Cancer Res.26:400-411.

Fantini N., Cabras C., LOBINA C., Giancarlo C., Gessa G.L., Riva A., Donzelli F., Morazzoni P., Bombardelli E. and Carai M.A.M. (2009).

Reducing effect of a Phaseolus vulgaris dry extract on food intake, body weight, and glycemia in rats. J. Agric. and Food Chem., 57:9316-9323.

Fernandez-Orozco R., Zielinski H.and Piskuła M.K. (2003).

Contribution of low-molecular-weight antioxidants to the antioxidant capacity of raw and processed lentil seeds. Nahrung/Food, 47 (5):291-299.

Fossati P. and Prencipe L. (1982).

The determination of triglycerides using enzymatic methods. Clin. Chem., 28: 2077.

Gawlik-Dziki U. and S'wieca M. (2011).

Sprouts of selected plants as a source of bioavailable antioxidants and lipoxygenase inhibitors. Annales UMCS Lublin, Sectio DDD, 23(3): 161-168 (439).

Harman D. (2009).

Origin and evolution of the free radical theory of aging: a brief personal history. Biogerontology, 10(6):773-781.

Harnafi H., Aziz M. and Amrani S. (2009).

Sweet basil (ocimum basilicum L.) improves lipid metabolism in hypercholesterolemic rats. e-SPEN, the Euro. e-J. Clin. Nutr. And Metab. 4: e181-e186.

Helmstädter A. (2010).

Beans and diabetes: Phaseolus vulgaris preparations as antihyperglycemic agents. J Med Food, 13: 251-254.

Henry R.J. (1964).

Colorimetric method to determination serum total protein: Clinical Chemistry. Harper and Row, New Yark, pp: 181.

Je J.Y., Qian Z.J., Byun H.G. and Kim S.K. (2007).

Purification and characterization of an antioxidant peptide obtained from tuna backbone protein by enzymatic hydrolysis. Process Biochem. 42:840-846. 
Kalogeropoulos N., Chiou A., Ioannou M., Karathanos V.T., Hassapidou M. and Andrikopoulos N.K. (2010). Nutritional evaluation and bioactive microconstituents (phytosterols, tocopherols, polyphenols, triterpenic acids) in cooked dry legumes usually consumed in the Mediterranean countries. Food Chem., 121:682-690.

Koracevic D., Koracevic G., Djordjevic V., Andrejevic S. and Cosic V. (2001) Method for the measurement of antioxidant activity in human fluids. J. Clin. Path. 54:356-361.

Li X.M. (2007).

Protective effectof Lycium barbarum polysaccharides on streptozotozin-induced oxidative stress in rats. Int. J. Biol. Macromol, 40: 461-465.

Malaguti M., Dinelli G., Leoncini E., Bregola V., Bosi S., Cicero A.F.G and Hrelia S.(2014).

Bioactive peptides in cereals and legumes: Agronomical, biochemical and clinical aspects. Int. J. Mol. Sci, 15: 21120-21135.

Maria M., Maria G., Corina M., Carmen D. and Alexandra T.(2007).

The sources and the targets of oxidative stress in the etiology of diabetic complications. Rom. J. Biophys. $17(2): 63-84$.

Mathers J. C. (2002).

Pulses and carcinogenesis: Potential for the prevention of colon, breast and other cancers. British Journal of Nutrition, 88: S273-S279

Moser K., Seelenbinder F., McFadden S., Adkins C., Goshay M. and Davis F(2001).

Selecting a new analyzer for the hematology laboratory: The experience at Ohio Health Hospital.In:Laboratory Hematology.7:245-254.

Ohkawa H., Ohishi W., Yagi K. (1979).

Assay for lipid peroxides in animal tissues by thiobarbitutric acid reaction. Anal. Biochem. 95:351-358.

Oomah B.D., Caspar F., Malcolmson L.J. and Bellido A.S. (2011).

Phenolics and antioxidant activity of lentil and pea hulls. Food Res. Inter., 44: 436-441.

Reeves P.G., Nielsen F.H. and Fahey G.C. (1993).

AIN-93 purified diets for laboratory rodents: final report of the American Institute of Nutrition Ad HOC writing Committee on the reformulation of the AIN-76 a rodent diet. J. Nutr., 123(12): 1939-1951.

Reitman S. and Frankel S. (1957).

A calorimetric method for the determination of glutamic oxalacetic and glutamic pyruvic transaminase. J. Clin. Path., 28:56 - 63. 
Egypt. J. of Nutrition and Health Vol. 10 No. 1 (2015)

Rizkalla S. W., Bellisle F. and Slama G. (2002).

Health benefits of low glycemic index foods, such as pulses, in diabetic patients and healthy individuals. British Journal of Nutrition, 88: S255-S262.

Rotruck J., Pop A., Ganther H., Swanson A., Hafeman D. and Hoekstra W. (1973).

Selenium biochemical role as acomponent of glutathione peroxides. Science, 179: 588-590.

Salem A. Amany, El-Bostany A. Nahla, Al-Askalany A. Samia and Thabet A. Hala. (2014).

Effect of domestic processing methods of some legumes on phytochemicals content and in vitro bioavailability of some minerals. Journal of American Science; 10(12).

Sharma R.D., Raghuram T.C. and Rao N.S. (1990).

Effect of fenugreek seeds on blood glucose and serum lipids in type I diabetes. Eur. J. Clin. Nutr. 44: 301-306.

Shimoda H., Tanaka J., Kikuchi M., Fukuda T., Ito H., Hatano T. and Yoshida T. (2008).

Walnut polyphenols prevent liver damage induced by carbon tetrachloride and $\mathrm{D}$ galactosamine: Hepatoprotective hydrolysable tannins in the kernel pellicles of walnut. J. Agri. Food chem. 56 (12):4444-4449.

Siah S.D., Konczak I., Agboola S.,Wood J.A. and Blanchard C. (2012).

In vitro investigations of the potential health benefits of Australian-grown faba beans (Vicia faba L.): Chemopreventive capacity and inhibitory effects on the angiotensin-converting enzyme, a-glucosidase and lipase. British Journal of Nutrition, 108:123-134.

Snedecor G.W. and Cochran W.G. (1989).

Statistical methods. The lowa State University Press. Ames, Lowe.

Srichamroen A., Thomson A.B.R., Field C.J. and Basu T.K. (2008).

In vitro intestinal glucose uptake is inhibited by galactomannan from Canadian fenugreek seed (Trigonella foenum graecum L) in genetically lean and obese rats. Nutr. Res. 29: 49-54.

Stein E.A. (1986).

In:Textbook of Clinical Chemistry.N.W.Tietz,ed.W.B.Saunders, Philadelphia.pp.879-886, 1818,1829.

Torres A., Frı'as J., Granito M. and Vidal-Valverde C. (2007).

Germinated Cajanus cajan seeds as ingredients in pasta products: chemical, biological and sensory evaluation. Food Chemistry, 101: 202-211.

Vadivel V., Stuetz W., Scherbaum V. and Biesalski H.K. (2011).

Total free phenolic content and health relevant functionality of Indian wild legume grains: Effect of indigenous processing methods. J. Food Comp. and Anal. 24: 935-943. 
Varley H., Gewenlock A. and Bell M. (1980).

Practical Clinical Biochemistry. Vol.1. $5^{\text {th }}$ Ed. Pp. 741, 897. London: William Heinemen Medical. Books, Ltd.

Wallach. J. (1992).

Interpretation of diagnostic tests. A synopsis of laboratory medicine. $5^{\text {th }}$ Ed. A little brown hand book, Boston.

Webster. D. (1974).

Colorimetric method to determine serum albumin. Clin. Chem. Acta. 53 (1): 109-112.

Winham D.M. and Hutchins A.M. (2007).

Baked bean consumption reduces serum cholesterol in hypercholesterolemic adults. Nutrition Research. 27:380-386.

Xu B.J. and Chang S.K.C. (2008).

Effect of soaking, boiling, and steaming on total phenolic content and antioxidant activities of cool season food legumes. Food Chem., 110:1-13.

Yang H., Chen S., Chang N., Chang J., Lee M., Tasi P., Fu H., Kao W., Chiang H., Wang H. and Hseu Y.(2006). Protection from oxidative damage using Bidens pilosa extracts in normal human erythrocytes. Food Chem. Toxicol. 44: 1513-1521.

Yoo Y.M., Nam J.H., Kim M.Y, Choi J. and Park H.J. (2008).

Pectolinarin and Pectolinarigenin of Cirsium setidens pervent the hepatic injury in rats caused by $D$ galactosamine via an antioxidant mechanism. Biol. Pharm. Bull., 31 (4):760-764.

Zahradka P., Wright B., Weighell W., Blewett H., Baldwin A., Karmin O., Guzman R.P. and Taylor C.G. (2013). Daily non-soy legume consumption reverses vascular impairment due to peripheral artery disease. Atherosclerosis, 230: 310-314. 
Egypt. J. of Nutrition and Health Vol. 10 No. 1 (2015)

التأثير الوقائى للبقوليات المطبوخة والمنبتة على بعض الاضطر ابات المصاحبة مع تقدم السن

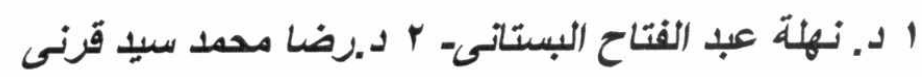

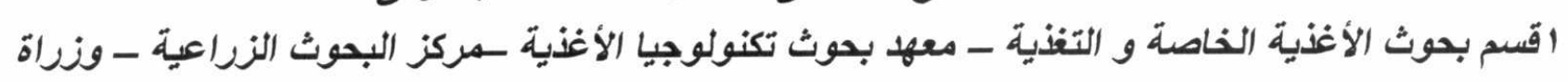

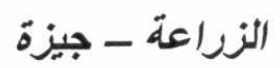

r - بسم الهيستوباثولوجى-كلية الطب البيطرى-جامعة القاهرة

المستخلص العربي

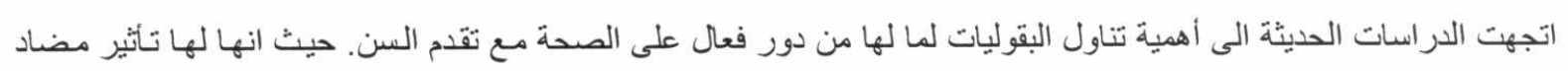

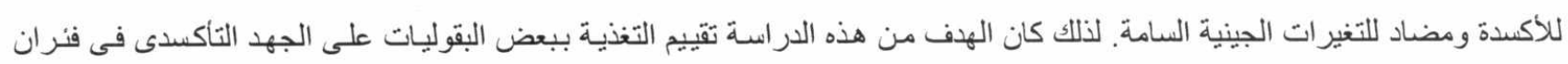

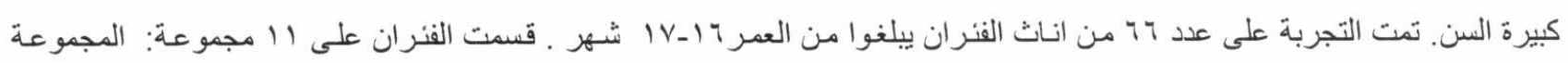

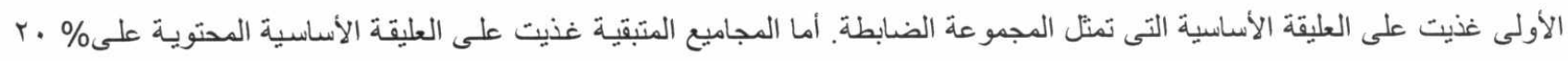

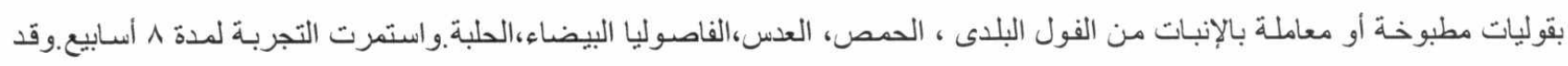

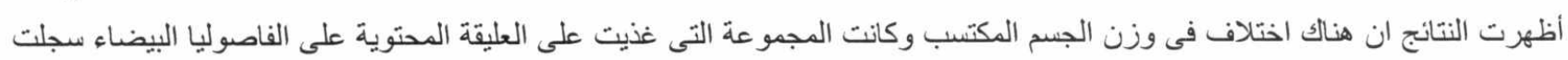

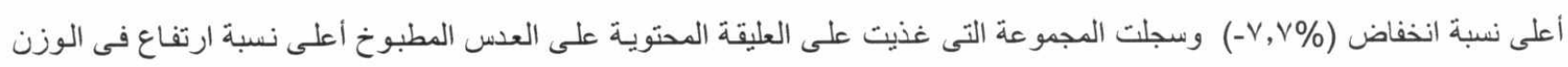

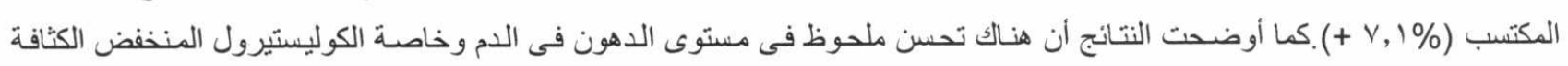

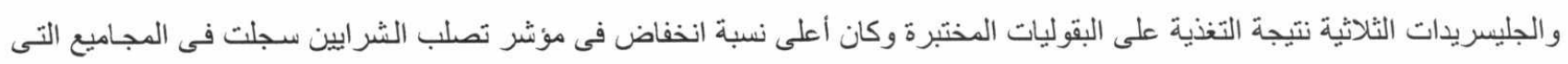

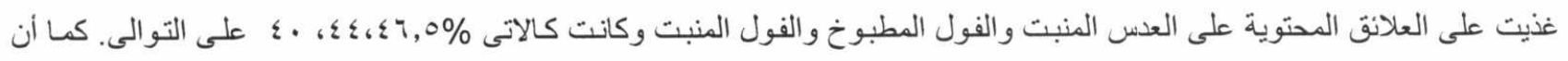

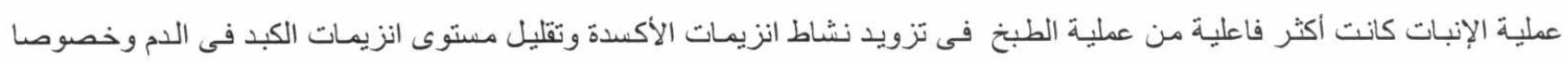

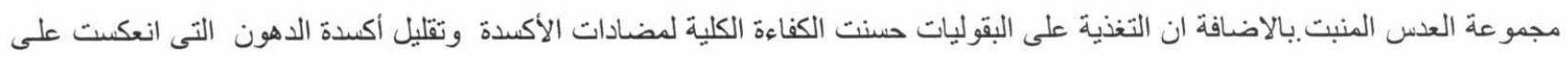

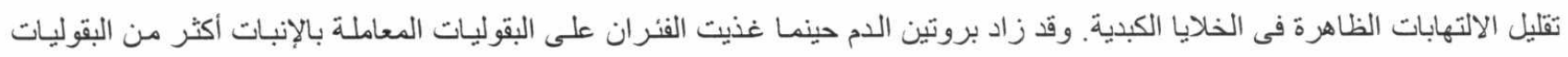

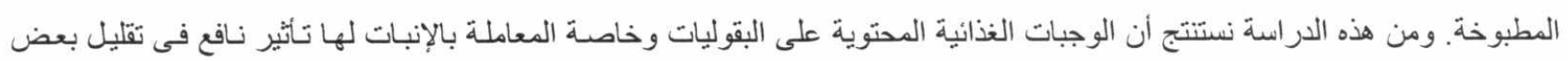

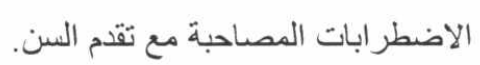

